\section{Nakasone to tackle Japan's research funding in last year}

WHAT will 1987 bring in Japan? Several of Prime Minister Yasuhiro Nakasone's major policy goals should be achieved the break-up of the national railways, tax reform, participation of Japan in the US Strategic Defense Initiative (SDI), finalization of plans for education reform and initiation of the Human Frontiers Science Program.

The Special Council on Education Reform set up by Nakasone in 1984 will make its final recommendations this year before being wound up in the summer. But it is hard to see how the council will be able to deal with the major problems besetting Japan's higher education system - elitism in the universities and the examination 'hell' confronting university entrants because they are simply too deeply engrained within Japanese society.

One measure that could, perhaps, have a significant influence on university education at the postgraduate level is the plan of the Ministry of Education, Science and Culture to form a graduate university to cater for the National Research Institutes for Joint Use by Universities, such as the molecular science, basic biology and physiological science institutes at Okazaki. The ministry has applied for funding for planning in fiscal year 1987.

Nobody yet knows what form the $\mathrm{Hu}$ man Frontiers Science Program will take, but it is intended to be an international research effort in basic bioscience. Sequencing of the human genome is another bioscience project that may emerge in Japan this year. The Science and Technology Agency, which is funding the development of an automatic DNA sequence analyser, has opened a 'window' of communication with the US Department of Energy and a formal agreement on information exchange is expected soon. The Frontiers programme arose in part out of criticisms that Japan takes more out of the pool of basic science than it puts in.

On 5 February, the X-ray astronomy satellite ASTRO-C, jointly developed by Japanese and British scientists, is due to be launched by the Institute of Space and Astronautical Science (ISAS) and will search for black holes and other X-ray sources. Soon after, ISAS's big brother, the National Space Development Agency (NASDA) is expected to launch the marine observation satellite MOS-1, to monitor ocean currents, water surface temperature, water vapour in the atmosphere and mineral and energy resources on land. NASDA will also launch an engineering test satellite, ETS-V, in the summer using a three-stage $\mathrm{H}-1$ rocket, following the successful launch of the twostage $\mathrm{H}-1$ last year.
This year will mark increased collaboration between the United States and Japan in the marine sciences. In January, the research vessel Natsushima of the Japan Marine Science and Technology Center will set out on a two-month survey of the western and central Pacific as part of the joint US-Japanese study of a suspected El Niño (see Nature 324, 504; 1986). From April to August, US and Japanese scientists will make dives in the US submersible Alvin in the fore-arc and back-arc regions of the western Pacific.

Japan's best chance to make a name for itself in basic science in 1987 will probably be in high-energy physics, however. TRISTAN, the $3-\mathrm{km}$ ring accelerator at the High Energy Physics Laboratory (KEK), has just undergone successful trial runs and the experimental programme should be in full swing by early May. With luck, KEK scientists may be the first to detect such elementary particles as the top quark and Higgs particle.

But it is Japan's technological feats that will continue to draw the world's admiration and ire. Construction of the new Kan-

\section{Prospects for 1987} Japan/Australia David Swinbanks in Tokyo Charles Morgan in Sydney

sai international airport - a massive civil engineering project involving the construction of an artificial island off Osaka - is about to get under way at a cost of 1 million million yen ( $\$ 6,000$ million).

Arguments between the United States and Japan over microchip trade seem destined to drag on interminably, and may take a strange twist - the Ministry of International Trade and Industry is contemplating accusing the US of dumping chips in Japan. But it is trade in supercomputers that seems likely to mark the next front in the high-technology war between the two world giants during the coming year.

The biggest event of 1987 will no doubt be the departure of Prime Minister Nakasone from office, which must come about before his term expires in October (unless he manages to bend party rules again). The changing of prime ministers in Japan is usually a non-event - policies carry on regardless. But Nakasone has clear-cut goals and has gone a long way towards achieving them. His implementation of tax reform and the break-up of the national railways, due to come into effect this year, may have a tremendous influence on science and technology in the long run, if they release much needed funding for the universities and research.

\section{Australia primes research pump}

For the Australian government, the main priority in science throughout 1986 remained the task of linking research more closely to the needs of industry in the hope that technologically stronger industries will eventually help to solve some of Australia's economic woes.

The message of technological prosperity being preached by Minister for Science Mr Barry Jones appears to have reached the government, judging from the 1986 budget. In a tight deficit-cutting budget, science held its ground and even made real advances in some areas such as the Australian Research Grants Scheme.

According to Jones, the new era in science is symbolized by the site for the A $\$ 18$ million National Science Centre within Canberra's Parliamentary Triangle which will give science a place alongside the palaces of the arts, law and letters. Much funding for the centre has come from Japan. Australian industry has a poor record of investing in research and many of Australia's largest companies are subsidiaries of multinationals which leave innovation to other branches overseas. At the same time, the Australian home market is too small to support much research.

The 150 per cent tax deduction scheme for money invested in research and development is the government's main strategy to attract investment. The scheme finished its first full year of operation in 1986 and seems to be working. Also attracted by a cheap Australian dollar, business is expected to spend about A $\$ 1,100$ million on research in $1986-87$, a doubling in real terms since 1981-82. 1986 also saw action on the recommendations of the Australian Science and Technology Council (ASTEC)'s review of the Commonwealth Scientific and Industrial Research Organization (CSIRO), Australia's largest research body. CSIRO has been encouraged to form new links with industry as a consequence of ASTEC's recommendations that CSIRO be allowed to keep any earnings arising from partnerships with industry without a corresponding reduction in its funding.

One issue that can be expected to come to a head in 1987 is the question of university funding, with the imminent release of an ASTEC report on university research. Both Prime Minister Bob Hawke and science minister Jones have spoken out on the need for more competitive funding criteria for university research. Steps have already been taken in the direction of concentrating more resources into fewer large grants to enable research programmes of particular excellence to buy major items of hardware within the Australian Research Grants Scheme. 